
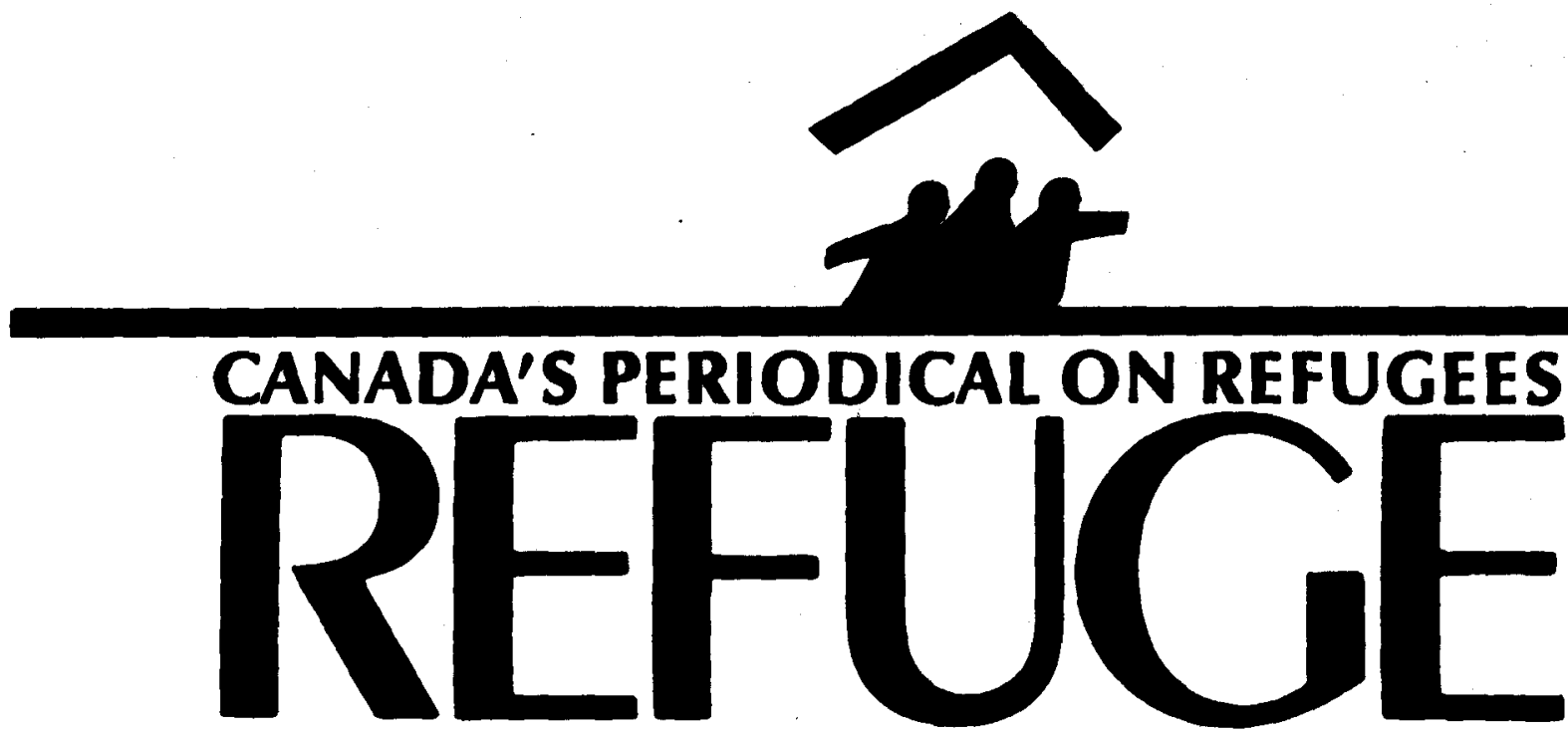

Vol. $14 \cdot$ No. 10

March 1995

\title{
SPECIAL IsSUe On Chechnya
}

\section{Chechnya: The Russian Policymakers Tragedy}

\author{
Tanya Basok
}

When the Soviet Union fell apart in 1991, many analysts applauded the peaceful way in which it happened. And in fact, it was peaceful. In contrast to Yugoslavia, there were no popular leaders committed to holding the Soviet Union together. Gorbachev's popularity at the time was very low and the populist leader Yeltsin, similar to other republican leaders, was only too anxious to dissolve the Soviet Union and assume presidency over the new political entity. Thus, in contrast to Milosevic of Yugoslavia, who was prepared to wage a genocidal war to prevent secession of Croatia, BosniaHerzegovina, and to a much lesser degree, Slovenia (for an update on the Yugoslavian crisis see Barutciski in this issue), Russian leaders who enjoyed popular support at the time were willing to let the republics become formally independent states. They did so always keeping in mind that it would be possible to establish economic, political, and military control over them at a later stage. So the partition was indeed smooth, although consequent struggles for autonomy in Abkhazia and Transdniester, and the Armenian claim to Nagorno-Karabakh did provoke wars.

While most nationalist aspirations in the former Soviet republics were thus peacefully satisfied, this was not the case of nationalist movements within the Russian Federation. Once formed, the integrity of the Russian sovereign state was not to be undermined by separatism in some of its semi-autonomous regions. Even mild claims for decentralization of federal - power are perceived by Moscow as a threat.

Thus the multi-ethnic Russian state was to become a federation with a strong central government that would grant no right to any of its semi-

\section{CONTENTS:}

Chechnya: The Russian Policymakers Tragedy

Tanya Basok

The War in Chechnya and the New Russian State

Sergei Plekhanov.

Chechnya: The War Without An End Alexander Benifand ................. $\quad 7$

The Chechen-Russian Conflict: The Spiral of Hostilities

Tanya Basok 10

Chechnya's Refugees Within North Caucasus:

Reality and Problems Eugene V. Kritski 13

Second World War, Refugee Flow and Forced Migrants in Russia Boris Kovalev

Safe Areas in Bosnia-Herzegovnia: Some Reflections and

Tentative Conclusions Michael Barutciski 


\section{REFUGE}

YORK LANES PRESS Centre for Refugee Studies Suite 351, York Lanes York University 4700 Keele Street, North York Ontario, Canada M3J 1P3 Phone: (416) 736-5843 Fax: (416)

736-5837 Internet: refuge@vm1.yorku.ca

Vol. $14^{-}$No. 10

March 1995 Editor C.

MICHAEL LANPHIER

Assistant Editors

VLADISLAV TUMIR

MARK SWINDER

Managing Editor ARUL

S. ARULIAH

Refuge is dedicated to the encouragement of assistance to refugees by providing a forum for sharing information and opinion on Canadian and international issues pertaining to refugees. Refuge was founded in 1981.

It is published ten times a year by York Lanes Press for the Centre for Refugee Studies, York University, Canada. Refuge is a nonprofit, independent periodical supported by private donations and by subscriptions. It is a forum for discussion, and the views expressed do not necessarily reflect those of its funders or staff.

All material in Refuge may be reproduced without permission unless copyrighted or otherwise indicated. Credit should be given to the author or source, if named, and Refuge. Submissions on related issues are welcome for publication consideration.

Current subscription rates for one

year (ten issues) are:

Canada Can.\$50

All other countries U.S. \$60. (Cheques must be drawn on a Canadian or a U.S. bank.) Single issues are available at $\$ 6.50$ per copy.

Please enclose your purchase order or payment, made payable to York Lanes Press, with your order.

ISSN 0229-5113 autonomous regions to self-determination. And those who dare challenge this arrangement should be prepared to have their territories invaded, their population killed and their leadership deposed. The tragedy that has engulfed Chechnya is the focus of study of this issue of Refuge.

As Benifand analysed, this was, in fact, the fate of the Chechen republic. As Basok argues, this current conflict in Chechnya has long roots and can be explained by a chain of events that intensified the already problematic ethnic relations between the Russians and the Chechens. But analysis of the violent reaction to Chechen claims to independence should also be placed, as Plekhanov rationalizes, within the current context of developing authoritarian rule in Russia. This factor has become even stronger as a result of the military operations in Chechnya (see Benifand) And, the ambivalence of the internationa response (see Benifand and Plekhanov) has allowed Yeltsin to pursue this policy with impunity. Even the tremendous human cost of this war (see the discussion of the violations of human rights and the refugee movement in Basok, Benifand, and Kritski in this issue) did not seem to alert the Western political leaders sufficiently for them to impose sanctions against Russia.
The question that needs to be addressed is: how durable is a federation ruled hegemonic ally from the centre? This would depend on a number of factors, including: the nature and extent of political control, economic disadvantages and/or social neglect experienced by the population in the regions; presence of leaders who can translate grievances related to disadvantages into nationalist aspirations and formulate the ideological platform for their struggle; and the degree to which those with nationalist claims believe that the centre is likely to accept them as legitimate and negotiate a solution acceptable to all parties.

With respect to the last point, Yeltsin's military action in Chechnya was a clear message to other nationalists within Russia that Moscow does not accept any challenges to the state's integrity. Thus, even in the presence of the first two factors, fear of retribution may dissuade some leaders of the Russian republics. If however, nationalist leaders in the republics perceive that the central power weakens (and this perception does not have to be realistic), we are likely to witness an explosion of pent-up nationalist aspirations. How much military power will Moscow use then? How many civilians will be killed? And how many people will become homeless? $\mathrm{m}$

Tanya Basok, Guest Editor

\section{CRS Eastern Europe and Central Eurasia Refugee Monitor Unit Editorial Advisory Board}

Audrey Alstadt, History, University of Massachusetts

Tanya Basok, Sociology/Anthropology, University of Windsor Alexander Benifand, Centre for Refugee Studies, York University

Robert J. Brym, Sociology and Centre for Russian and East European Studies, University of Toronto

Mirjana Morokvasic, Centre national de la recherche scientifique, Paris Endre Sik, Social Science Information Centre, Budapest

Galina Soldatova, Institute of Ethnography and Anthropology, Russian

Academy of Sciences, Moscow 